\title{
Trilateral relations among China, Nepal and India: Opportunities, Challenges and Prospects
}

\author{
Barack Lujia Bao 8(D) \\ Researcher and Faculty Fellow, Department of Foreign Studies, Xianda College of Economics and Humanities of Shanghai \\ International Studies University, Shanghai, China \\ $\triangle$ Corresponding Author: Barack Lujia Bao, E-mail: baolujiamzd@qq.com; 2011068@xdsisu.edu.cn
}

\author{
ARTICLE INFORMATION \\ Received: June 08, 2021 \\ Accepted: July 10, 2021 \\ Volume: 3 \\ Issue: 7 \\ DOI: $10.32996 /$ jhsss.2021.3.7.2
}

\section{KEYWORDS}

Belt \& Road Initiative; China-NepalIndia Trilateral Relations; Neighbourhood Policy; Transnational Connectivity; Regional Challenges and Prospects

\section{ABSTRACT}

Through multiple cases, comparative analysis, and empirical analysis, the purpose of this essay attempts to examine the triangular interaction among China, India and Nepal from the geopolitical and geoeconomic perspectives. It can be observed that the progress over intensive cultural exchanges among China, Nepal and India has been a little bit more noticeable and more substantive than interstate economic engagement. The comparison between the China-initiating Belt and Road Initiative and India's neighbourhood policy shows that both major economies tend to be strategically vying for constructive partnership in South Asia. Furthermore, Nepal's proposal of trans-Himalaya connectivity provides a crucial, intermediary trade alternative among these three economies in promotions of mutual economic growth and prosperity. This essay chiefly argues that both Nepal and China, as the two chief emerging powers in Asia, are encouraged to play a much more proactive role in fostering trilateral connectivity, whilst India as a member of BRICS should revamp its foreign policy considerations to fully utilise India's neighbourhood policy and meanwhile acquaint itself with China's Belt and Road Initiative to facilitate regional growth at an interstate level that can share beneficial trilateral interests. This essay unveils a more accurate, comprehensive scenario of BRI-generating linchpin of triangular China-Nepal-India ties that is heterogeneous to the neoliberal system.

\section{Introduction}

China, Nepal and India are these three major countries that are equipped with a vast horizon of economic opportunities. The population of both India and China accounts for around 37\% of the entire global population (Hurworth, 2019). With the competitive advantage of a huge population, both China and India, these two economic powers, are strategically vying for geopolitical and geo-economic influence in South Asia in some ways. China puts forward the concept of Belt and Road Initiative (BRI) as a fresh paradigm of cooperation for economic development and multilateral connectivity, whose proposal to a large degree pays more attention to trans-regional connectivity with South Asia with special priority, while India has comparably envisioned its concept of 'Neighbourhood Policy' under Modi's Prime Ministership to establish India's new foreign policy initiatives in the region to keep stabilising its influence. Nepal, as a member between India and China, presents itself with ample opportunities to bridge socioeconomic interaction between these two economically emerging giants. There has been relentless discourse about Nepal's foreign policy and shifting alliances between India and China. As a result of the case study, this paper chiefly argues that China is encouraged to play a more consequential role in further boosting economic development in Nepal, and India needs to cautiously re-think its foreign policy if India seeks to exert a constructive influence in South Asia.

China's rapid economic growth, by the grace of the last four decades of reform and opening up, has led it to emerge as the secondlargest economy in the world and China's interaction with the rest of the globe has been more amplified. It can be observed that to some extent, few Chinese top policy decision-makers have launched such frequent global routes and exchanges within such a short period in a way that Chinese President Xi Jinping has done (Global Business Outlook, 2017). Statistically speaking, since 2013,

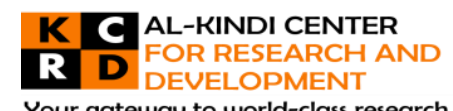

Your gateway to world-class research

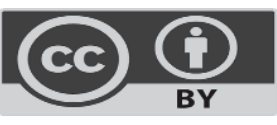

Published by Al-Kindi Center for Research and Development. Copyright (c) the author(s). This open access article is distributed under a Creative Commons Attribution (CC-BY) 4.0 license 
Chinese President Xi has 'logged 28 overseas trips over 56 countries', and CNBC has acknowledged Xi as a global leader filling in the vacuum left by Donald Trump(Foudy, 2018). Similarly, China has also positioned itself as a driver of inclusiveness and participatory development endeavours with alternative countries and regions. Nowadays, China accounts for $12.4 \%$ of the global trade, approximately $\$ 4.6$ trillion(China Power, 2020). Part of China's soft-power international development policy, i.e. Belt and Road Initiative, is considered as a vital catalyst for creating larger economic projects by promoting economic cooperation that mutually aligns with the interests of emerging markets, thus creating a win-win prospect and the major economies in South Asia sees the Belt and Road Initiative with great enthusiasm as China nowadays holds as a critical trading partner in South Asia. In the case of Nepal, it is high time that Nepal utilised Chinese assistance and investment for the sake of economic growth (Subedi, 2018). Larger groups of South Asian academics, professionals, and intellectuals identify the Belt and Road Initiative as a rare opportunity with the capacity of enhancing the prospect of civic prosperity through the ways of bridging the infrastructure gap (Sangraula, 2019). On the contrary, the Belt and Road Initiative seemingly contradicts a disputing claim by India as the latter one sees the Belt and Road Initiative as an instrument of minimising India's traditional influence in South Asia. Sangraula (2019) highlights that when China is pushing forward the BRI among South Asian countries such as Nepal, Pakistan, Sri Lanka and Bangladesh, India is adopting a sub-regional concept like the Bhutan-Bangladesh-India-Nepal partnership (BBIN). Therefore, maintaining a striking balance of powers has been of much high priority within some non-industrialised economic powers of little influence across South Asia.

China shares trade development with seven out of eight South-Asian countries and has been the largest investor and trading partner for six out of eight SAARC nations (Sharma \& Khatri 2019). If a comparison between India's presence and China's presence in South Asia is made, according to a study from Brookings Institution, India's trade volume with South-Asian members remains less than $4 \%$ of its entire global trade, while China's trade volume has escalated from $\$ 8$ billion in 2005 to $\$ 52$ billion in 2018(Hindustan Times, 2020). It can be observed that India fairly defines the Belt and Road Initiative as a potential infiltration of Chinese influence on its geostrategic sphere that tends to undermine India's role in South Asia. India needs to realise that there is little to gain in creating economic stagnation in the region through the conflict of taking advantage of China-India security dilemma card with other regional economic actors such as Pakistan, Nepal or Bangladesh.

In contrast, the Belt and Road Initiative is guided by mutual benefits. There is a reason why China tends to advocate the concept of economic reciprocity over conditionality-based foreign aid. Economic cooperation would imply that both sides receive economic benefits with mutual collaboration and an ensuing win-win scenario is vitally predictable. The Belt and Road Initiative is therefore envisioned as a key economic growth catalyst that can allow the South Asian economies to expedite trans-regional trade. Considerable parts of the South Asian economies are throttled in low-GDP per capita, the fairly beleaguered democratic institutions and yet-to-be-sophisticated market mechanisms, thus depriving large populations of a better standard of living. Until 2015, the population from South Asia accounted for 33.4\% of the underdeveloped across the globe (Mazhar \& Goraya, 2015). South Asia fairly confronts infrastructure deficit and lacks the morale of industrial output and structural transformation. China is not a direct part of the South Asian region. It shares an observer-branding status in the South Asia Association for Regional Economic Cooperation (SAARC). Fortunately, by the grace of economic and trade cooperation and people-to-people diplomacy, China constitutes an integral part of economic linkages and cooperation. For example, during the first Belt and Road Initiative Forum in 2017, Chinese President Xi Jinping stated that China's trade volume with other countries along the BRI route 'exceeded $\$ 3$ trillion (2014-2016), and China has invested over $\$ 50$ billion in participating nations, followed by the creation of over 180,000 jobs' (Xi, 2017). It can further be stated and argued that it is implausible to ignore China's role in the economic development and prosperity of South Asia.

The paper is divided into different parts as follows. To begin with, the paper attempts to examine the duality and complex ramification of the neoliberal world order chiefly designed by the US and a supplementary role of the Belt and Road Initiative in galvanising interstate economic partnership with little conditionality. Furthermore, the paper seeks to identify and evaluate the strength and experience of China's development model that the other South-Asia economic members are encouraged to take seriously and carefully. Next, the paper tends to assess the role of India's Neighbourhood Policy in complex regional development in comparison with China's ones. Last but not least, the paper attempts to evaluate a potentially desirable scenario and the prospect of trilateral relations between China, India and Nepal, especially in the domains of infrastructure cooperation and cultural exchanges that benefit most members within South Asia.

\section{The Belt and Road Initiative and a World Order}

The present neoliberal international order, chiefly designed and dominated by the United States after World War II, has served as its global ambition of an open international economic system. The United States claims that it advocates for vibrant democracies, free market access, prioritisation of human rights, all through the creation of liberal multilateral institutions like the World Bank and International Monetary Fund (Kagan, 2017). Such neoliberal international financial institutions play duality-oriented roles in designing economic policy interventions that follow the liberal institutions and governance mechanism. For instance, the IMF is solely in charge of monitoring compliance to provide financial assistance underwriting its own rules of the game (Truman, 2017). However, it has fostered much expansion of the liberal institutions that sought resources from non-industrialised economies and 
has witnessed the rise in conflicts across poorer economies. For example, the ill-designed World Bank project in Ethiopia destroyed indigenous inhabitants' lifestyle, crops and fertility of the land in an effort to supply electric power to the capital Addis Ababa(Adams, 1992). Quite differently, the economic cooperation model fostered by China in the past four decades urges the world to see that new initiatives to creating a new world order are certainly plausible if emerging markets seek to get rid of their narrow self-interests and collectively demanding for mutually benefiting partnership to expedite shared development(Sangraula, 2019). For instance, China's investment in leather in Ethiopia has provided employment to $90 \%$ of indigenous people and generated large foreign currency and extensive funding from local governments for a more sustainable future (Daily Motion, 2015) The past four decades of China's reform and opening-up policy has not just showcased China's exponential economic-growth potential, but also provided an alternative means for infrastructure development across developing countries and emerging markets. Part of such concepts introduced by China for international partnership and cooperation is popularly conceptualised and cemented into the Belt and Road Initiative, which is China's ambitious attempt to inter-connect parts of Eurasia and Africa through the land and sea route with a massive infrastructure investment spending spree. Since 2013, this Initiative has spanned across 70 countries in Eurasia and Africa, with estimated Chinese investments overarching $\$ 4$ trillion (Hillman, 2018). Global participation in the BRI was expanded from 6 percent to 18 percent across 22 countries between 2014 to 2017 (Guo, 2018). All of this state that those countries and economies are willing to cooperate with China-initiating BRI and that there is a positive outlook of the Belt and Road Initiative across developing countries and regions. With boosting infrastructure development across the non-industrial powers, it has meanwhile created a favourable geo-economic environment for China as China has a big current account surplus, and Chinese investments abroad releasing some pressure on China's currency help its export industries (Chang 2019).

The BRI has led to the development of a new model for infrastructure cooperation. Since the 2008 global financial crisis, there has been a lowering trend of investing in infrastructure spending. Globally, around $30 \%$ of the potential benefits from infrastructure investment are lost due to inefficiencies in investment planning and implementation and corruption, lower fiscal literacy countries, especially those in South Asia, which would see even more inefficiencies in investment (IMF, 2015). In that regard, Yakunin (2019) argues that on the one hand, the government reduced investment in long-term infrastructure, while on the other hand, private investors switched from 'infrastructure spending towards more liquid assets' with swift returns that can give them rapid success. The BRI's accomplishments can be demonstrated by the ability of China in associating different parts of its own country with the finest roads and fast-track railways networks, which has proved its vitality spectacularly. China has significantly invested in its transportation infrastructure in order for interurban market resources and growth. For instance, its total investment in fixed transport connectivity was RMB 609.11 billion in 2008, which was 76 times higher as compared to the standard in 1978 (Nannan, et al., 2012). It is a contributing factor for lifting hundreds of millions of population out of extreme poverty. The realisation has been an exemplification of the fact that for economic growth, there needs to be access to an expansive market and it is facilitated through transport connectivity. Thus far, the BRI has embraced six different prime economic corridorsas: China-Mongolia-Russia Economic Corridor, New Eurasian Land Bridge, China - Central Asia Economic Corridor, China - Indo-China Peninsula Economic Corridor, and BCIM economic corridor and the China Pakistan Economic Corridor, which above all has proven out to be the highlight of the BRI initiative (Gill, et al., 2019).

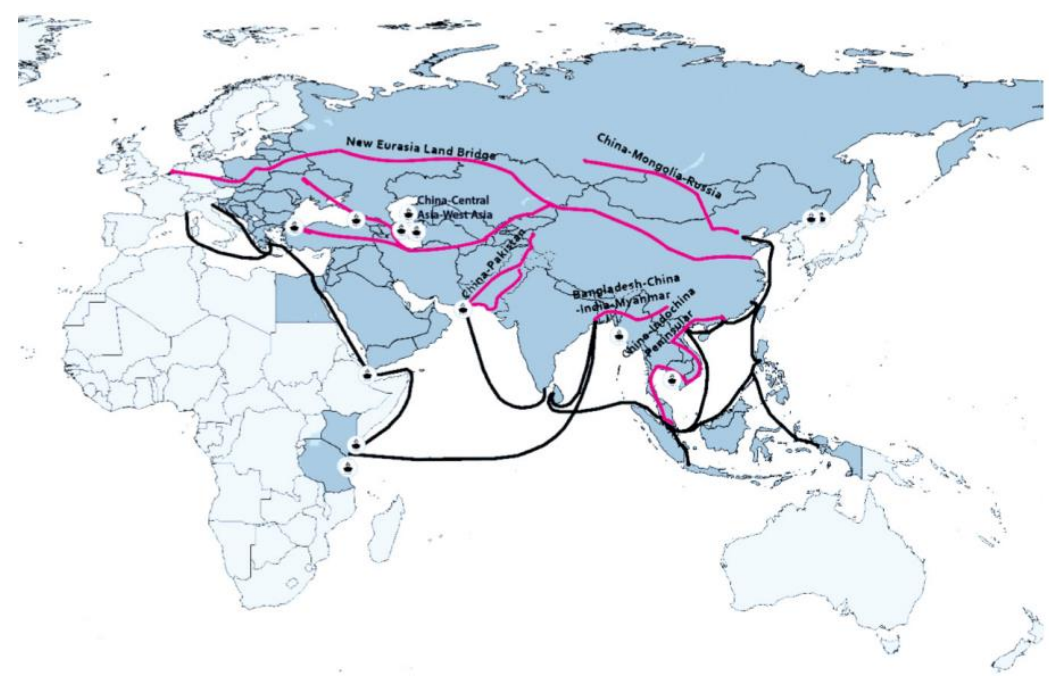

Note: From "Figure 1: The Silk Economic Belt \& New Maritime Silk Road," by World Bank, 2019, Belt and Road Economics: Opportunities and Risks of Transport Corridors, p.3. Copyright 2019 by World Bank. Reprinted with permission. 
There is a widespread phenomenon that China has gradually shifted away from its traditional narrative of becoming an inwardlyfocused economy towards putting itself on a global stage and bearing more international responsibility. Most of the Western media tend to be sceptical about China's Belt and Road Initiative, implying it as propaganda to advance Chinese national interest. One article from the China Africa Project states that most of the Western media perception about the BRI has been on the issue of 'debt trap diplomacy' highlighting as a threat to the liberal interests (The China Africa Project, 2019). The current development trajectory of China is considered a major threat to its liberal values by the force of the cold-war mentality in the United States. On the contrary, China asserts that it is not in a position to challenge the existing neoliberal world order. China has neither the intention nor capability to supplant the existing world order (Zhao, 2016). China's economic engagement with a vast majority of countries not singularly in South Asia but also Eurasia has consistently claimed that the BRI is an open, participatory approach where any nation is open to join the initiative as long as the win-win prospects can be witnessed in the world order.

It can be highlighted that the Belt and Road Initiative would become an important aspect of China's diplomacy and leads to the rejuvenation of the European continent (Khatri \& Sharma, 2019). China has placed a great emphasis on mutual connectivity because development is implausible without collaboration in today's complicated, interconnected world. Its pivot on driving and sustaining economic globalisation is more pronounced than ever as the guidelines released. China plans to promote mutual inclusiveness by bringing all relevant stakeholders together in the sphere of global development. Comparatively speaking, the United States needs over $\$ 1.5$ trillion in infrastructure spending, in addition to repairing existing crumbling infrastructure (Moak, 2019). The United States takes the development of China as a dwindling of dominance that has squandered its numerous opportunities. Moak (2019) argues that the Trump-launching trade war did not reduce the US deficits but instead has raised production costs, therefore unveiling a significant disadvantage for US consumers and US enterprises' production costs. As China's foreign policy is entitled to a no-strings-attached policy, it is of dire importance that the BRI covers some of the world's most populous countries with complex social structures. The rise of China has lifted the international brand of Asia at large, and so has done so by the rise of India and the other economies in South Asia. China is the world's leading practitioner of geo-economics (Blackwell \& Harris, 2016). Many results have made it spectacular that the rise of China, as well as the rise of emerging markets and powers in South Asia, is affirmatively reshaping the structure and dynamics of present globalisation, and then vitally consequential for having a bigger scope and prospect for a new kind of globalisation that share more interests for more members. Meanwhile, China's responsibility also comes in supplying important international public goods without falling into the 'Kindleberger trap' (Zheng, 2020). There is generally a positive response to China's influence on the international stage through mutual collaboration, and it becomes imperative to provide constructive international leadership at the time when there is political resentment from the Western Hemisphere with increasing resentment, restrictions and negative populism.

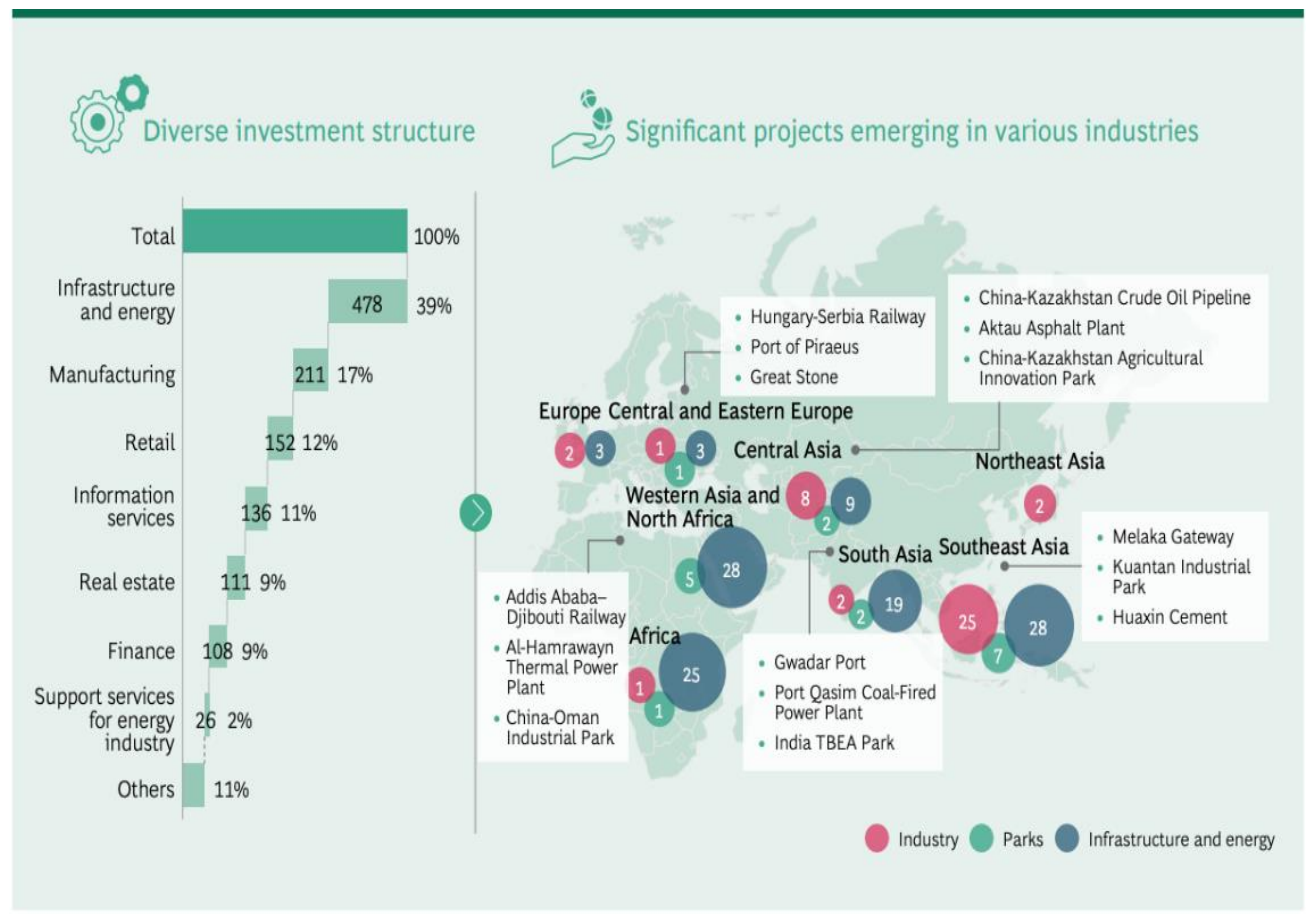

Note: From "Exhibit 3: Chinese Investments in BRI Countries," by Y.Zhou. \& A. Xie, A. \& F. Lu. \& K. Zhang, 2018, The Belt and Road Initiative: an Inclusive and Symbiotic Approach to Shared Prosperity, p 4. Copyright by Zhou, et al. Reprinted with permission. 
Every crucial investment launched by China has not singularly benefited the other major countries but also benefited China itself thus exemplifying the win-win cooperation.

\section{Experience of China's Model for the South Asia Economies}

In Asia, both China and most of the major countries in South Asia have suffered significantly from devastating colonial rule for almost two centuries (Szczepanski, 2021). From a geopolitical standpoint, South Asia is considered to be one of the important and complex regions. In addition to political factors, the economic rise of the region unveils a considerable interest in how an international relationship can interact. At present, four of the top ten fastest-growing economies in the world come from South Asia: Bangladesh, Bhutan, India and Nepal. However, despite continuing economic growth, the unsophisticated institutional structure has been a prime characteristic of the region. In Nepal, for instance, in two decades after 1990, the so-called liberal democracies were characterized by traits and stigmas of political malfeasance, criminalisation of politics and poor governance, and the absence of overall, coordinated development of their societies in pursuit of liberal democracy. It is divisive by substance and keeps continuously making societies divisive. South Asia, in general, has significantly blindly fallen into an acute trap of this unfitting, unmatched Western style of democracy, which truly represents a state of the quagmire in governance.

In contrast, China's BRI as part of a peaceful-rise strategy is the inherent principle that China here is persisting for mutual benefits of the population as the centrepiece of the Initiative (Sharma \& Khatri, 2019). There is a need to examine the parameters of its success to achieve political stability in the society, rapid economic development, financial discipline of the State and continuous process of reform of laws and intuitions. It can be argued that a country must adopt its own system of democracy that is a genuine fit in its special national circumstances. The theory of Chinese-style democracy can be elaborated as the collective, centralised system of people's congress, multi-party collaboration and political consultation, regional autonomy as well as self-governance, all of which seek to promote continuous social self-improvement and development (Sangraula, 2019).

The steady progress made by China and other economies in Asia is a direct consequence of the pursuit of innovative policies and programmes in economic and social development. The traditional western model may tend to partially divide the political world into 'good' democracies and 'poor' authoritarian regimes(Bell, 2015). However, China's model follows the 'gradualism and experimentation' approach in its development. China's gradual approach towards experimenting with huge policy changes normally primarily starts at a local level and then is implemented nationwide. The villagers figured out that the traditional 'work point' system was the root cause of poor production and thus implemented reform measures to allow households to retain certain savings, which boosted production. Economic, social and development rights are cemented merely into an issue of fundamental demand instead of an 'optional' right. Conceivably, China has engaged extensively in infrastructure development and knowledge transfer through advanced education and capacity-building upgrading. For instance, we can refer to Shenzhen SEZ case in 1978 where the initial delegates were sent to Hong Kong of China to gain knowledge of technological progress and how best to achieve it inside the mainland of China (Child, 2013). Such an environment for adaptability and knowledge sharing has facilitated China to progress rapidly. On the contrary, neoliberalism has also brought about rapid widening inequality and unfair wealth distribution across the region. In India, the top 10 percent of the people control almost all the wealth and further the 1 percent of rich Indians have been getting more wealthy than the remaining 99 percent (South Asia Alliance for Poverty Eradication, 2019). This is in addition to larger gender disparity in the workforce, health services, education standards, and government efficiency. In Nepal, privatisation took over after 1990 under the mandate of its 'liberalisation' policies, which became in favour of the private sector economy and destroyed much of the normal economic process. These policies have generated huge malpractice and averse aftermath of its economy. Considerable economic state entities of South Asia has failed to take scientific education as a prelude to economic development. Instead, most South Asian economic powers blindly follow the Western-neoliberalism approach in education, which includes privatising educational institutions and universities and benefiting the few while ignoring the larger needs of the marginalised. Therefore, privatisation along with structural adjustments and promoting a pure-Western-style freemarket economy crumble the education, health and overall development system inside the South Asian territories and South-Asia members have not taken the strength and experience of China's development model seriously and carefully.

Making no mistake, South Asia as China's closest neighbouring region represents a completely different reality in matters of quality of economic development. Whilst the South Asian economic development has witnessed unprecedented growth, the same has been suffering from a quagmire of widening inequality over regions, population and income. Taking lessons from China's economic and development patterns, it is important that prioritising and optimising societal development be consequential and imperative for overall South Asian economic powers because the scientific outlook for development that prioritises economic construction as the chief pivot of its work is vitally required and because it lays considerable emphasis upon coordinated and collaborative development (China Daily, 2007). There needs to be a more pragmatic approach drawing from China for scientific advancement in order for the betterment of regional development. 


\section{India's Neighbourhood Policy in South Asia \& Modi Doctrine}

India's neighbourhood policy in South Asia during the first five-decade period (1947-1996) was a contradiction between what was claimed on the world stage and what was implemented on the ground. Vinay Kaura (2020) argues that at an international level, India 'rejected the notions of balance of power and followed the Non-Alignment Movement (NAM)', however within its neighbourhood, India sought to have its own sphere of influence inside the South Asian region. Consequently, India was strongly 'opposed to intervention by major powers in the internal affairs of the weaker ones, but within the subcontinent, 'it had to perform the function or provide security to the smaller nations and their regimes' (Mishra, 2018). This was seen as India's duality-oriented neighbourhood policy and India itself contradicted its belief by constantly meddling in the internal affairs of non-industrialised economic powers inside the South Asia region. For instance, the Kashmir-relevant issue remains the cited reason for almost three wars between India and Pakistan (Ayres, 2020). Cross-border terrorism and confrontation in Kashmir, border disputes across Lipulekh with Nepal and Dokhlam with China and Bhutan, and watering territorial issues in Bangladesh have made India's foreign policy unexpectedly unfavourable in South Asia.

India has been following the 'neighbourhood policy' since the prime ministership of Jawaharlal Nehru. In another instance, India's relationships with Bhutan have been guided by strong bilateralism with influence in domestic affairs that allows India to exert its influence over Bhutan even during the Dokhlam crisis. Whilst India has invariably claimed primacy in the South Asia region, economic integration of the subcontinent has not been viewed as a national priority due to inward economic orientation. South Asia's response to globalisation has also created regional integration measures like the Bangladesh-Bhutan-India-Nepal (BBIN) Corridor, Bay of Bengal Initiative for Multi-Sectoral, Technical and Economic Cooperation (BIMSTEC), and South Asia Association for Regional Cooperation (SAARC), etc. India's recent sustained high annual economic growth over the years helps India to take advantage of it to advance its self-serving narrow interest in the South Asia region.

\section{Percent change, $y-0-y \quad$ Real GDP Growth in South Asian Countries}

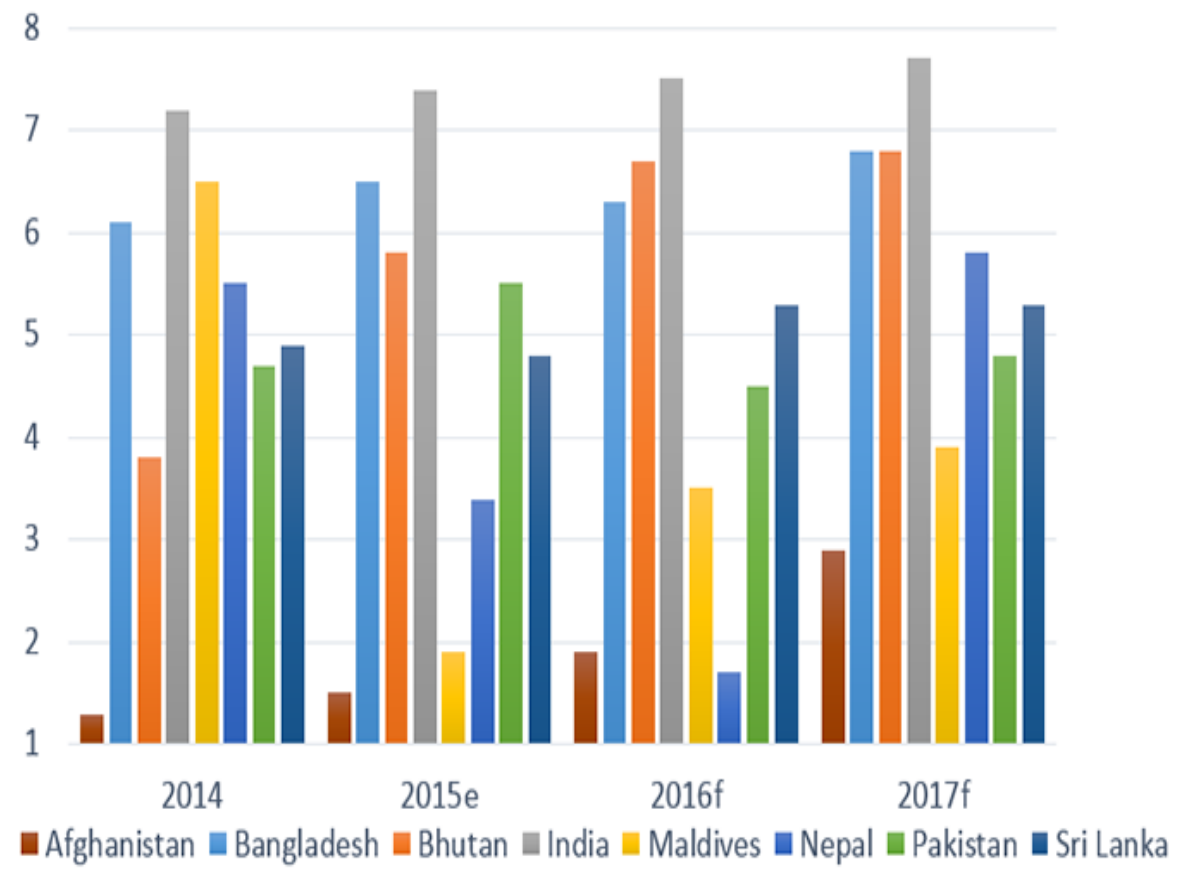

Note: From "Real GDP Growth in South Asia Countries" by World Bank, 2016, South Asia Remains World's Fastest Growing Region, but Should Be Vigilant to Fading Tailwinds. https://www.worldbank.org/en/news/press-release/2016/04/09/south-asia-fastestgrowing-region-world-vigilant-fading-tailwinds, Copyright 2016 by World Bank, Reprinted with permission. 

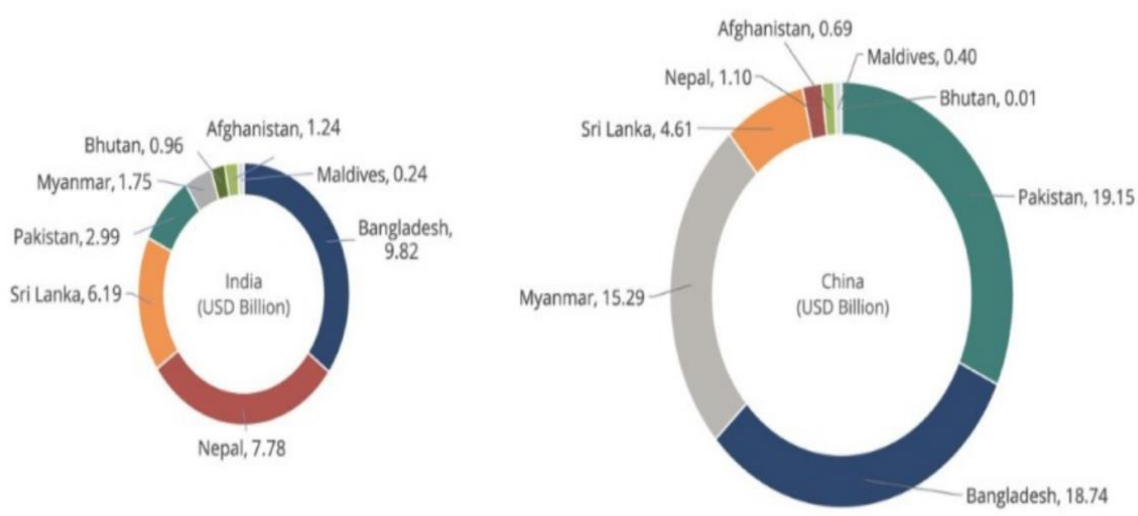

Note: From "Statistics of India's Trade with South Asia and China's one with South Asia" by R. Sinha \& N. Sareen, 2020, China's trade with India's neighbours has grown stronger since 2005. Delhi must catch up. https://theprint.in/opinion/chinas-trade-withindias-neighbours-has-grown-stronger-since-2005-delhi-must-

catch-up/433327/. Copyright 2020 by R. Sinha \& N. Sareen, Reprinted with permission.

Whilst India may attempt to fashion for itself a new international identity through its engagement with all major economic powers, it cannot drift away from the fact that it possesses a complex geo-political environment under difficult geographical conditions. Not surprisingly, India's relation with the South Asian neighbouring countries has often been the focus of Indian diplomacy. Continuing with this tradition, 'Neighbourhood First' has been the striking feature of the Modi Administration's diplomatic approach. It can be suggested that India should resolve its differences with its small neighbouring countries, project better scenarios and prospects and foster enhanced connectivity.

India's South-Asia policy under 'Modi Doctrine' seeks to focus on tightening the bond between India and its neighbours, and better serving India's economic and social development strategy by promoting regional and sub-regional connectivity. Narendra Modi, who often projects himself as an influential Indian leader to influence the South Asian dynamics, has visited 4 times in the last 5 years to the Himalayan state, launching an ice-breaking breakthrough over the traditional norm of no bilateral exchange between India and Nepal at prime ministerial levels(Lokantra, 2018). However, much powerful as he had influence in his initial tenure, Modi's influence dwindled in 2015, when India imposed the economic blockade in Nepal. Nepal, which was experiencing some of the most perilous times in restoring peace and stability after the earthquake, was faced with a massive economic blockade across the southern region of Terai, cutting off all the supplies and distribution network. This led to the spark rise in prices, shortage of essential needs and supplies, followed by the increasingly negative attitudes or even resentments towards New Delhi. Modi's unpredictable power on foreign policy has led some commentators to suggest that the Modi Administration's foreign policy has marked the emergence of the Indian 'Third Republic', which commenced with Modi at the helm of affairs, with a non-ideological worldview guiding India's global ambitions (Sirohi, 2015). However, structural problems have often imposed limitations on Modi's political ambitions for India. As Sumit Ganguly pointed out, there has been no fundamental transformation of India's foreign policy since Modi's hope to transform India's relations with China and Pakistan and to extend India's influence in South Asia (Ganguly, 2018).

Unlike China, India's leadership desire under 'neighbourhood policy' has failed to provide transport and infrastructure connectivity in the region. For instance, there is no passenger rail link between India and Nepal or Myanmar (Singh, 2017). The India Bangladesh rail link decreased from around a dozen in the 1960s to just one in the mid-2000s (Mahmun, 2017). In the case of Nepal, there is still no direct flight connecting India and Nepal till 2017; instead, there was only one non-stop flight between New Delhi and Dhaka (Xavier, 2020). However, there has been some bottlenecks removed since Modi's visit to Nepal. For example, to monitor the progress of bilateral achievements between Nepal and India, Modi reinstated the biennial commission, thanks to frequent dialogue between India and Nepal after 23 years, has been witnessed. On the contrary, it can comparably be observed that at a governmental level, there remain a lot of constraints about political discontinuity and India should try to undertake benign, constructive, responsible leadership if it seeks to establish itself as a significant regional hub again.

\section{Trilateral Cooperation: Opportunities, Challenges, and Prospects}

While the cooperation may have diminished since the Belt \& Road Initiative was questioned and doubted by India, Chinese policymakers' visit to Nepal has brought a fresh chapter to trilateral cooperation under the $2+1$ framework i.e. China-India plus framework, which will promote trilateral cooperation between these countries (Nepal, 2020). India and China are the rising 
economic powers. India, has the world's largest youth population with 356 million youths (UN, 2014), while China boosts the world's largest middle-income population with over 500 million people showing prospects for larger economic cooperation(Cheng, 2019). Nepal's core competency for economic development lies in tourism and Nepal's open border with India provides Nepal with comparative advantages to facilitate a large number of annual Indian tourists for cultural visits. However, when it comes to the issue of infrastructure investment, there are numerous complexities between major economies. The prime concern has to do with India's unwillingness to engage with China. India, despite one of the largest loan recipients of the Asian Infrastructure Investment Bank (AIIB), bears a diplomatic rivalry with China when it comes to India's growing geopolitical and geo-economic influence in South Asia. India's traditional sphere of influence has allowed it to provide security on its interests, but with China now being the largest trading partner in South Asia, India needs to cautiously re-think its neighbourhood policy. The classical dichotomy of India being an ancient civilisation and interstate relationship as 'brotherhood relationship' with India require much comprehensive, credible, long-term re-examination because the current political trends and perception of India seem to proceed in an opposite direction. Indian sub-continent remains extremely divided with minimum interconnections. Thus, despite Modi's frequent visits and appeal for regional cooperation, India's regional conquest, to a large extent, has partly become a victim of its own accomplishments, exposing serious geopolitical and geo-economic pitfalls.

\subsection{Transport Connectivity and the Role of Nepal}

Transport connectivity, therefore, constitutes the prime strategic importance of the China-Nepal-India economic corridor. There is more reason to believe that Nepal can generate peaceful development and mutual collaboration between both sides. The case of Myanmar can reinforce that argument. It is worth noting that India and Myanmar share a $1600 \mathrm{KM}$ border much of it along the remote and volatile northeast frontier. The Bangladesh-China-India-Myanmar (BCIM) Corridor poses equal opportunities but challenges remain not just to land routes, but also seaports. The geo-politics and geo-economics regarding governmental involvement across the BCIM have been of no difference across other initiatives like SAARC. Furthermore, there is also a dilemma between regionalism and sub-regionalism through multiple corridors, not to mention the issues of the border with China and the potential volatility of the South Asia region. Many regional initiatives have been considerably driven by political motives; therefore, Nepal as an intermediary actor, despite being in the middle of China and India, can provide much better transit opportunities for both economies as well as the macroeconomically-beneficial interests.

Concerns in India remain about the trans-Himalaya corridor leading to Chinese goods that will be flocking over the Indian market via Nepal, which has the potential to put the local industries at a competitive disadvantage. However, such concerns require effective, inclusive, representative economic policies and frequent engagements among the three stakeholders without being restricted within political interests alone. For example, Nathula Pass is a pass on the Indo-Sino border, which may be the singular operational trade route between China and India over their long border, which was closed off after the 1962 war and reopened in 2006, though it still carries limited trade volume between the two major economies as the two BRICS members. Although they standoff at a sensitive, volatile juncture, along with the Dokhlam issue, it is likely to increase Nepal's visibility to act as a bridge between both two major countries in advancing such an economic corridor.

India's approach, as well as China's one, to Nepal, is a tale of two intersections. On the one hand, India and Nepal benefit from strong people-centric relationships through similar languages. However, their interstate political tensions at governmental levels have restricted expansive cooperation over the years with the prevailing anti-Indian sentiment across the people in Kathmandu and beyond. On the other hand, however, the China-Nepal relationship has been most prevalent at a governmental level, with very limited people to people engagement. Furthermore, the Chinese diplomatic principle of 'non-interference' entails much respect to Nepal's sovereignty, but on the other hand, such cooperation has not yet been fully translated into reality at the people-topeople level. Much of the efforts of both governments now are in enhancing people to people diplomacy with concrete efforts to promote mutual cooperation, building a positive prospect of Nepal and China for the sake of benign economic cooperation. Therefore, by the grace of the efforts of Nepal, there has to be a balanced regional approach that promotes a kind of peoplebased diplomacy across both India and China as well as mutual understandings among government entities across all three fronts, providing a model for effective cooperation in a time of uncertainty.

\section{Conclusion}

Nepal's history of engagement with India and China shows that there is a tendency to strategically opt for one after another when it comes to foreign policy. Perhaps a key underpinning for Nepal's foreign policy is to align with the domestic needs and security interests. Both China and India's foreign policies are devised in need of maintaining maximum domestic stability and minimum regional security deficit. Nepal's foreign policy, due to recurrent changing government chronologically, had been characterised by changing priorities depending on the position of top policy decision-makers. China-initiating Belt and Road Initiatives offer a considerable prospect for Nepal's future development, but it also comes with careful consideration of projects, keeping in mind capacity, sustainability, development paradigms and national security interests. Similarly, concerns with India about engagement with China should be dealt with proper communication of the interests of Nepal and that India oversees Nepal as a sovereign and 
independent state rather than as a 'buffer state' where India, in the past, had only been concerned about the security interests, with little regards to economic or social development.

In a nutshell, the China-Nepal-India Trans-Himalaya Corridor presents a viable opportunity for future collaboration and economic engagement across three countries. The corridor passes through Himalaya terrain, with immense potential of conducting extensive sustainable cultural tourism development in South Asia. The China-Nepal-India triangular engagement has been illustriously defined by the spread of culture and art, but little was talked about economic trade, politics and prosperity over the years. Recent engagement between these countries shows that it is all about economic cooperation that will eventually lead to fostering of art and culture, which will much re-shape the relationship among these countries.

\section{References}

[1] Adams, P. (1992). The World Bank and IMF in sub-Saharan Africa: Undermining Development and Environment Sustainability, Journal of International Affairs, $\underline{46(1)}, 97-117$.

[2] Ayres, A. (2020). The conflict between India and Pakistan. https://www.cfr.org/global-conflict-tracker/conflict/conflict-between-india-andpakistan.

[3] Bell, D. (2015). The China Model: Political Meritocracy and the Limits of Democracy, Princeton University Press.

[4] Bhatt, C. (2017). Geopolitical Crisis between Nepal and India, Kantipur Daily.

[5] Blackwill, R.D. and Harris, J.M. (2016). War by Other Means - Geo-economics and Statecraft. Harvard University Press.

[6] Chang, F. (2019, August 6). Unequal Sequal: China's Belt and Road Initiative. https://www.fpri.org/article/2019/08/unequal-sequel-chinasbelt-and-road-initiative/

[7] Cheng, E. (2019, September, 30). China's giant middle class is still growing and companies from Walmart to start-ups are trying to cash in. https://www.cnbc.com/2019/09/30/chinas-giant-middle-class-is-still-growing-and-companies-want-in.html

[8] Child, J. (2013). The dynamics of corporate co-evolution: A case study of port development in China, Edward Elger publishing limited.

[9] China Daily. (2007, October). Scientific Outlook on Development. http://language.chinadaily.com.cn/2007-10/12/content_6170884.htm

[10] China Daily. (2016, August). Chinese tech to make Himalaya train possible. http://en.people.cn/n3/2016/0805/c202936-9095559.html

[11] China Power. (2020, June). Is China the world's top trader?. https://chinapower.csis.org/trade-partner/

[12] Daily Motion. (2015). Chinese company brings Ethiopia's leather industry to life, https://www.dailymotion.com/video/x3gincg.

[13] Foudy, J. (2018, April 12). How China's Xi Jinping is filling the 'global leadership vacuum' left by Trump. https://www.cnbc.com/2018/04/12/chinas-xi-jinping-is-filling-global-leadership-vacuum-left-by-trump.html.

[14] Ganguly, S. (2018). Modi's Foreign Policy Revolution? In India, Radical Change Is Hard to Come by. https://www.foreignaffairs.com/articles/india/2018-03-08/modis-foreign-policy-revolution.

[15] Gill, I. \& Lal, S. V. \& Lebrand, M. (2019). Winners and losers along with China's Belt and Road, Brookings Institution.

[16] Global Business Outlook. (2017). Chinese Foreign Policy With Xi Jinping Characteristics. https://www.globalbusinessoutlook.com/chineseforeign-policy-with-xi-jinping-characteristics/

[17] Guo, M. (2018, January 11). 2016-2017 China National Image Global Survey. https://us.kantar.com/business/brands/2018/2016-2017-chinanational-image-global-survey/

[18] Hillman, J. (2018, January 25). China's Belt and Road Initiative: Five Years Later. https://www.csis.org/analysis/chinas-belt-and-road-initiativefive-years-later-0

[19] Hindustan Times, (2020. May 28). India's trade with South Asia less than 4\% of global trade; China's up by 546\%. https://www.hindustantimes.com/india-news/india-s-trade-with-south-asia-less-than-4-of-global-trade-china-s-trade-with-regionincreases-by-546/story-NqV2EfMvnpjypgV6LFPiwO.html

[20] Hurworth, E. (2019, June 19). India to overtake China as the world's most populous country. https://edition.cnn.com/2019/06/19/health/indiachina-world-population-intl-hnk/index.html

[21] International Monetary Fund. (2015, May 1). Making public investment more efficient, https://www.imf.org/external/np/pp/eng/2015/061115.pdf.

[22] Kagan, R. (2017, January 25). The twilight of liberal world order. https://www.brookings.edu/research/the-twilight-of-the-liberal-world-order/

[23] Kharel, P. (2018). From Tatopani to Rasuwa-an analysis of Nepal-China trade after the earthquake, MPRA.

[24] Khatri, R. S. \& Sharma, B. (2019). The Politics of Soft Power: Belt and Road Initiative as a Charm Influence in South Asia, World Scientific Publishing.

[25] Kumar, R. (2020, June 5). New China-Nepal Rail Corridor. https://www.nepalitimes.com/latest/new-china-nepal-rail-corridor/.

[26] Lokantra (2018). Indian PM Modi to visit Nepal again in November. http://english.lokaantar.com/world/pm-modi-visit-nepal-november/

[27] Mahmun, S. (2017, April 5). Government to restore rail links to India, Nepal, Bhutan. Dhaka Tribune. http://www.dhakatribune.com/bangladesh/foreign-affairs/2017/04/05/govt-restore-rail-links-india-nepal-bhutan/

[28] Mazhar, M. S. \& Goraya, N. S.(2015). Issues of Good Governance in South Asia. South Asia Studies, 30, 125 - 160.

[29] Moak, K. (2019, April 30). Why the US should join in BRI. https://news.cgtn.com/news/3d3d414d32597a4d34457a63333566d54/index.html

[30] Nannan, Y. \& Dong, M. D. \& Storm, S. \& Mi, J. (2012). "The growth impact of transport infrastructure investment: A regional analysis for China (1978-2008)". Policy and Society. 31(1), 25-38

[31] Nepal, R. (2020, January 4). Envoy Hou terms China - India plus trilateral cooperation. https://thehimalayantimes.com/kathmandu/envoyhou-terms-china-india-plus-trilateral-cooperation/

[32] Sangraula, Y. (2019). South Asia - China Geo-economics. Lex and Juris Publication. 
[33] Sharma, B. P. \& Khatri, R. S. (2019). The Politics of Soft Power: Belt and Road Initiative (BRI) as Charm Influence in South Asia. International Journal on Belt and Road Initiative: China and the World: Ancient and Modern Silk Road. https://www.worldscientific.com/doi/abs/10.1142/S2591729319500020

[34] Singh, K. (2017, June 15). Nepal revamps colonial-era railway line. https://www.aol.com/article/news/2017/06/15/nepal-revamps-colonialera-railway-line/22287945/

[35] Sinha, R. \& Sareen, N. (2020). China's trade with India's neighbours has grown stronger since 2005. Delhi must catch up. https://theprint.in/opinion/chinas-trade-with-indias-neighbours-has-grown-stronger-since-2005-delhi-must-catch-up/433327/.

[36] Sirohi, S. (2015, July 23). PM Narendra Modi's foreign policy: new or an assertive version of old?. https://economictimes.indiatimes.com/blogs/letterfromwashington/pm-narendra-modis-foreign-policy-new-or-an-assertive-version-ofold/

[37] South Asia Alliance for Poverty Eradication. (2019). Growing inequality in South Asia: South Asia inequality report 2019, SAAPE.

[38] Subedi, M. (2018, April 23). Nepal and South Asia Welcome Chinese FDI to Boost Growth. http://www.chinadaily.com.cn/a/201804/23/WS5add1332a3105cdcf6519c0d.html

[39] Szczepanski, K. (2021, February 27). Which Asian Nations Were Never Colonized by Europe?. https://www.thoughtco.com/asian-nations-notcolonized-by-europe-195273

[40] The China Africa Project. (2019, October 21). How the U.S. Media Perceives and Communicates Chinese Railway Projects in the Belt and Road Initiative. https://chinaafricaproject.com/student-exchange/how-the-u-s-media-perceives-and-communicates-chinese-railway-projects-inthe-belt-and-road-initiative/

[41] Truman, E. M. (2017, October). The End of the Bretton Woods International Monetary System. https://www.piie.com/publications/workingpapers/end-bretton-woods-international-monetary-system

[42] Vinay Kaura, M. R. (2020). India's Neighbourhood Policy During 2014- 2019: Political Context and Policy Outcomes, Indian Journal of Public Administration, 66(1), 10-27

[43] United Nations. (2014, November 18). India has the world's largest youth population, well ahead of China: UN report. https://www.firstpost.com/world/india-worlds-largest-youth-population-well-ahead-china-un-report-1808537.html

[44] World Bank. (2019, June 18). Belt and Road Economics: Opportunities and Risks of Transport Corridors.

[45] https://www.worldbank.org/en/topic/regional-integration/publication/belt-and-road-economics-opportunities-and-risks-of-transportcorridors

[46] World Bank. (2016, April 9). South Asia Remains World's Fastest Growing Region but Should Be Vigilant to Fading Tailwinds. https://www.worldbank.org/en/news/press-release/2016/04/09/south-asia-fastest-growing-region-world-vigilant-fading-tailwinds,

[47] World Economic Forum. (2016, June 10). Insight Report: the Human Capital Report 2016, World Economic Forum Report. http://www3.weforum.org/docs/HCR2016_Main_Report.pdf

[48] Xavier, C. (2020, January 21). Sambandh as strategy: India's regional approach to connectivity. https://www.brookings.edu/wpcontent/uploads/2020/01/India's-New-Approach-to-Regional-Connectivity-V3_M.pdf

[49] Xi Jinping. (2017, May 14). Full Text of President Xi's Speech at Opening of Belt and Road Forum. http://2017.beltandroadforum.org/english/n100/2018/0306/c25-1038.html

[50] Yakunin, V.(2019, April 30). The Belt and Road Initiative as a New Model for Global Inclusive Development and Solidarity. https://docresearch.org/2019/04/the-belt-and-road-initiative-as-a-new-model-for-global-inclusive-development-and-solidarity/.

[51] Zhao, S. (2016, July). China as a Rising Power versus the US-led World Order. https://risingpowersproject.com/quarterly/china-as-a-risingpower-versus-the-us-led-world-order/

[52] Zheng, Z. (2020, March 19). How Asia perceives China in the context of BRI: Evidence from an Asian poll. https://theasiadialogue.com/2020/03/19/how-asia-perceives-china-in-the-context-of-bri-evidence-from-an-asian-poll/.

[53] Zhou, Y. \& Xie, A. \& Lu, F. \& Zhang, K. (2018). The Belt and Road Initiative: an Inclusive and Symbiotic Approach to Shared Prosperity, Boston Consulting Group. 